\title{
Kin-state politics stirred by a geopolitical conflict: Hungary's growing activity in post-Euromaidan Transcarpathia, Ukraine
}

\author{
Patrik TÁtRAI ${ }^{1}$, Ágnes ERŐSS ${ }^{1}$ and Katalin KOV ÁLY ${ }^{1}$
}

\begin{abstract}
In the last decades, as a result of intensified migratory movements, scholars have globally witnessed the proliferation of transnational migrant and diaspora communities in many cases challenging the traditionally conceived sovereignty of nation states and inducing policy answers in the field of migration and citizenship politics. In Central and Eastern European countries, citizenship issues have been embedded in kin-state politics due to the existence of great number of ethnic-kin communities living in the territory of a neighbouring or nearby host countries. That is especially true to Hungary that has elaborated a sophisticated system of kin-state policies composing inseparable factor both in its domestic and foreign politics. The ongoing crisis in Ukraine generated such push factors that resulted in boosting out-migration in its westernmost region, Transcarpathia, where sizeable ethnic Hungarian community resides. The out-migration is further facilitated by pull factors manifested in intensified political presence and kin-state politics of Hungary, Poland and Czechia, three Visegrad countries in need of fresh labour force. The present paper - after reviewing recent migratory processes - offers an analysis on the interrelatedness of migration, geopolitics and kin-state politics in Transcarpathia. We argue that Ukraine's crisis resulted in a major shift in regional geopolitical power relations opening the floor to the Visegrad countries to intensify their presence and influence in Western Ukraine, primarily seeking for human resources to satisfy their demographic and workforce needs. Focusing on Hungary, we intend to prove that the out-migration of Transcarpathian Hungarians posed a serious challenge to the well-built system of Hungarian kin-state policies resulting in major modification of measures targeting Transcarpathia. We point to the ambiguous nature of the prime kin-state policy measure, the dual citizenship without residency introduced in 2010 by Hungary, arguing that following 2014 in the post Euromaidan Transcarpathian context it represents a tempting pragmatic tool embodying practical opportunities, even material benefits attractive for all Transcarpathians, including non-ethnic Hungarians. Finally, we conclude that Hungary's kin-state politics not only contribute to the decrease of the number of Transcarpathian Hungarians, but there is a high risk that - with their Hungarian citizenship - they will resettle in Western Europe, not in Hungary.
\end{abstract}

Keywords: kin-state politics, migration, Ukraine crisis, Transcarpathia, Hungary, Poland, Czechia

\section{Introduction}

Globalization poses various challenges to the nation states. With the intensified spatial mobility of people more and more nation states have found themselves in a situation in which they need to tackle the effects of losing ethnic-kin citizens due to emigration or demographic decline, while at the same time new, non-ethnic immigrants settled in their territories. Many scholars claimed that "The growing international mobility of people questions the basis of belonging to the nation state" (CAstles, S. and Davidson, A. 2000, vii-viii) and called attention on that traditional understanding of citizenship are needed to be reframed taking into consideration the multiple and multi-layered links people connected to more than one state and society. While some envisioned the erosion of traditional understanding of nation state sovereignty opening the floor to post-national or transnational state formations and cosmopolitan or transnational citizenship (Pogonyi, S. 2011), others pointed out that the proliferation of multiple citizenship still

\footnotetext{
${ }^{1}$ Geographical Institute, Research Centre for Astronomy and Earth Sciences, MTA. H-1112 Budapest, Budaörsi út 45. E-mails: tatrai.patrik@csfk.mta.hu, eross.agnes@csfk.mta.hu, kovaly.katalin@csfk.mta.hu
} 
suggests the importance of nation state as a political entity and citizenship as a legal and symbolic form of belonging to it (PerchINIG, B. and Вачвӧск, R. 2005).

Research on migration and politics of citizenship issues in Europe often articulate the difference between Western and post-communist Eastern European countries in this sense. While multiple citizenship has been more and more generally accepted in many European states, there is a major WesternEastern diversion in the aim and scope related regulations. The citizenship policies of post-communist Eastern European states focus primarily on co-ethnics and diaspora living abroad, while pay very limited attention to the immigrants and the integration of immigrants. In Central and Eastern European (CEE) countries, due to the frequent geopolitical changes, ethnic boundaries and political borders do not overlap, that provides a whole different context and actuality to citizenship and kin-state politics. In contrast, dual citizenship in Western Europe is rather treated as a tool to mitigate and enhance the integration of immigrants (HowARD, M.J. 2009, 177-178; Sievers, W. 2009, 455; PogonyI, S. 2011, 693). Furthermore, in many CEE countries dual citizenship is seen as a "threat by an external kin state to the jurisdiction of a neighbouring state over a part of its citizen population and over the territory in which these minority citizens live" (Вачвӧск, R. 2007, 74). Conceiving dual citizenship as a tool for "expanding the national community beyond state borders" (BAUвÖск, R. 2007, 70) is well-grounded in the rich literature revealing the politics of citizenship in post-communist countries (Kulu, H. 2000; Faist, T. and Kivisto, P. 2007; Bauböck, R. et al. 2009; Iordachi, C. 2013; AgARIN, T. and Karolewski, I.P. 2015)2. These studies reflect on the implication of dual citizenship as an element in the toolkit of kin-state politics, which is in the focus of present research.

\footnotetext{
${ }^{2}$ See also the thematic issue of Minority Studies published in 2013: http://bgazrt.hu/npki/ folyoiratok_en/minority_studies_2012_2015_en/ minority_studies_16_szam_1/
}

According to one definition, kin-state politics cover actions to engage and protect the so-called ethnic kin communities in neighbouring or nearby states (WATERBURY, M. 2014). Kin-state politics can cover various actions that can be grouped as political-legal (legal and diplomatic advocacy), economic (launching financial aid or other business oriented programme), cultural (establishment and funding of kin community educational, cultural, etc. institutions, scholarship programme) and symbolic (the inclusion of co-ethnics e.g. by offering citizenship) (Waterbury, M. 2010).

In general kin-state politics target two groups: transborder ethnic communities and ethnic diasporas. The main difference among these groups is how they are formed: transborder ethnic minorities emerge due to geopolitical changes and/or shifting borders (e.g. Poland, Hungary, Germany) thus these communities became mere victims of political reordering many cases living en masse along the redrawn borders (PogonyI, S. 2011); while ethnic diasporas are rather formed through migration (e.g. Armenian, ex-Yugoslav or Turkish diasporas in Germany) and many cases settled far from their homeland. Kinstate politics, including citizenship politics, are sculpted by interests and preferences of at least three involved parties, namely the state, the kin-state and the co-ethnic group (Brubaker, R. 1996). Primarily the fear of insecurity and maintenance of territorial sovereignty explains the heated debate about citizenship and kin-state politics as it "raises fundamental questions of loyalty and identity, and in many cases perceived as threats by the state on which territory the co-ethnic group resides" (WATERBURY, M. 2010, 2-4).

It is important to highlight that offering non-resident citizenship by a kin-state to the co-ethnics is often a tool serving opportunistic purposes typically applied by nationalist parties to gain domestic political support. This is especially true when non-resident citizenship comes with voting rights that is suitable to influence parliamentary elections in the kin-state (e.g. Croatia). On the other hand, 
any sign of political activation of co-ethnics in the host state is perceived a risk as "no sovereign state welcomes the political mobilization of its minorities by its kin-states" (PogonyI, S. 2011, 692). Considering ethnic minority and diaspora, non-resident citizenship unquestionably conveys a symbolic value, quasi incorporating them to the majority society, but it would be naive to deny the practical side citizenship carries, as it makes available the incorporated benefits (e.g. health care system, free education, free travel).

Furthermore, kin-state policy interventions are formed by domestic politics and external threats and opportunities (WATERBURY, M. 2010, 16). Any change in any of the factors will result in modification of the whole system, generating response. For instance, in case of Romania, the EU accession as an external factor, required some fine-tuning in the system, which resulted in the drop of the number of dual citizenship granted to Moldovan citizens (IordACHI, C. 2013).

Among the diverse systems of kin-state politics described in CEE countries, Hungary is an extraordinary case due to the wide net and complexity of such politics provided by the country. This is a consequence of the existence of more than 2 million transborder ethnic Hungarians once belonged to Hungary but now forming minority communities mainly along the state border in the neighbouring countries (Austria, Slovakia, Ukraine, Romania, Serbia, Croatia, Slovenia). Consequently, kin-state politics have been essential factor in Hungary's domestic and foreign politics (BÁrdi, N. 2011; KánTOR, Z. 2014). In the past couple of decades, after the collapse of socialism, Hungary has developed a well-grounded system of kin-state politics offering cultural-economic programmes and providing political advocacy to the co-ethnic communities. Naturally, similar kin-state politics are in operation throughout Europe (e.g. Fowler, B. 2002; Csergő, Z. and Goldgeier, J. 2004; Tóth, J. 2006; Hatvany, C. 2006; Pogonyi, S. et al. 2010; WAterbury, M. 2014). What makes the "Hungarian model" slightly different is the level of activity of state poli- cies, complexity of programme, and high level of institutionalization (KÁNTOR, Z. 2014).

Hereby, we would like to call attention to the reconfiguration of Hungary's kin-state politics towards Transcarpathia, Ukraine following 2014. Primarily driven by domestic political motivations in 2010, the Orbán government's kin-state politics became stirred by the geopolitical conflict in Ukraine requiring prompt response to mitigate its consequences. The crisis in Ukraine started in 2013 when the pro-European Euromaidan protest heightened the tension dividing Ukraine to its breaking point (KARÁCSONYI, D. et al. 2014). Following the deadly clashes, the Russian friendly president, Viktor Janukovich left the country in February 2014. The new government not only had to manage the devastating economic situation, but soon it had to tackle the loss of Crimea and the hybrid war in Donbas. Three years have passed since the beginning of the weaponry conflict in Donbas, but every day shootings still take their victims, while two non-recognized puppet states were established in Eastern Ukraine. The political crisis and the armed conflict have soon turned into economic crisis as well; as a result, Ukraine as a state has weakened.

In this paper we will focus on the westernmost region of Ukraine, Transcarpathia, bordering Romania, Hungary, Slovakia and Poland. Transcarpathia (Zakarpattya, in Hungarian Kárpátalja, literally Subcarpathia) belonged to the Hungarian Kingdom, later to the Austro-Hungarian Monarchy. After the Treaty of Trianon in 1920, the region was granted to Czechoslovakia, but between 1939 and 1944 Hungary regained it back. Between 1945 and 1991 it was part of the Ukrainian SSR within the Soviet Union, and since 1991 it has been the part of independent Ukraine.

Although the ethnic diversity, characteristic of Transcarpathia hundred years ago, has decreased, still ethnic minorities constitute about 20 per cent of the 1.25 million inhabitants according to the 2001 census. Hungarians $(152,000)$ and Romanians $(32,000)$ live mainly en masse along the bor- 
der, but Russian, Roma, Slovak, and German communities also found home in the region. Even though the state authority has changed several times during the 20th century, the peripheral position of Transcarpathia remained constant under any state formation. Its ethnically diverse population structure made Transcarpathia susceptible to and subject of neighbouring states' politics, out of which Hungary's kin-state policies are in the forefront of present article.

Our goal is to identify the push and pull factors that trigger recent socio-economic and political processes in Transcarpathia (Western Ukraine) and the Visegrad Countries (V4). By analysing the case of Hungary's kin-state politics targeting post-crisis Transcarpathia we intend to show (1) how and in which ways a geopolitical conflict and its consequences may influence neighbouring or nearby states' kin-state politics; (2) how migration, both emigration and immigration, interfere with kin-state politics. Furthermore, (3) we briefly discuss the political and kin-state policy activities of neighbouring and nearby states, sometimes competing with each other, facilitated by the diminished power of the Ukrainian nation state in its westernmost periphery, Transcarpathia.

We argue that it was the consequences of Ukraine's geopolitical crisis generated such push factors that resulted in boosting out-migration from Transcarpathia, further facilitated by pull factors manifested in intensified political presence and kin-state politics of Visegrad countries are in need of fresh labour force.

The study is based on 26 semi-structured expert interviews conducted in spring 2016 in Transcarpathia and Budapest, complemented by information deriving from statistical data, policy documents, and field observation.

\section{Hungary's kin-state politics after 2010}

Hungary implemented wide net of policies for supporting Hungarian communities abroad even before 2010. Its basic, consensual goal was to maintain transborder co-ethnic communities in their homeland (see details in BÁRDI, N. 2011). The change of government in 2010, when right-wing Fidesz ${ }^{3}$ came into power, was accompanied by shift in Hungary's kin-state politics manifested in more diverse policy measures. The new government's very first measure serving the new paradigm in kin-state politics was the amendment of the Hungarian Citizenship Law resulted in a simplified naturalisation procedure coming into force in January 2011. This made it possible for people living in the former territory of the Kingdom of Hungary (i.e. the Carpathian ba$\sin$ ) to acquire Hungarian citizenship without residing in Hungary. Anybody is eligible for preferential (re)naturalisation who or whose ancestors held Hungarian citizenship once, and who proves his/her knowledge of the Hungarian language - thus the Law does not exclude individuals with non-Hungarian ethnic background from the benefits if they are able to speak Hungarian.

This law served both symbolic goals in the field of domestic politics like compensation for the failure of referendum about dual citizenship for kin-minorities abroad held in 2004 (see details in Kovács, M. 2007) supported by Fidesz (opposition party at that time) or the re-emerging nation-building project ("national reunification", PogonYI, S. 2015), and pragmatic goals such as to expand the governing Fidesz's voter base with new non-resident citizenship. The latter was made possible with the amendment to the Act on Electoral Procedure adopted in 2012, which allows non-resident Hungarian citizens to participate in Hungarian parliamentary elections. As studies (in keeping with our recent field experiences) have pointed out, this might be seen as a mere export of home affairs to the transborder Hungarian communities (PogonyI, S. 2014) with less consideration of its effect on specific minority identities or emotional consequences of the transborder Hungarian communities. Instead, dual citi-

\footnotetext{
${ }^{3}$ Fidesz: Fiatal Demokraták Szövetsége - Federation of Young Democrats.
} 
zenship can be seen as a tool for the power to manipulate transborder communities using them to tackle its legitimacy demand (PAPP, Z.A. 2017; Pogonyi, S. 2017).

Beyond the extended citizenship and voting rights, post-2010 kin-state politics contains several old or only redesigned policies. For example, the main goal of the policies for Hungarian communities abroad still aims at facilitating prosperity of Hungarian communities and preserving their identity in their homeland. Beside the aims in the field of identity politics, economic goals are becoming more and more important especially since 2014: "Hungary and the neighbouring countries have to strive to achieve positive economic developments in the region, which will motivate both younger and older generations to stay and work in their homelands" (MPAJ 2011, 13). From economic point of view, ethnic kin became valuable for Hungary for two reasons: they constitute a valuable asset, whose migration to Hungary would satisfy the country's demographic and labour force needs in the most cost-effective, smoothest way. At the same time, they are considered to be an asset as well if remaining in their homeland, because Hungary's kin-state politics can rely on them to fulfil Hungary's regional economic and geopolitical goals. As a Hungarian representative of kin-state politics put it:

“... these [transborder Hungarian] communities are considered to be a bridgehead in Hungary's economic expansion in the Carpathian Basin." (Representative of Hungarian kin-state politics regarding Transcarpathia, Budapest)

This calls attention to the (long-standing) conflict of interest of Hungary's kin-state politics: whether to help transborder Hungarian communities to stay in their homeland or enhance their migration to Hungary to satisfy the country's demographic and labour needs. Since the political transformations in 1989, all political forces in Hungary have explicitly supported the first goal; however, some of the measures implemented implicitly served the second aim. The amendment of the Hungarian
Citizenship Law reflects such controversies: however, it does not support directly ethnic kin's migration to Hungary but still facilitates it. Nevertheless, kin-state politics lacking a clear, coherent, one-way road, they serve both aforementioned directions instead. As ÇAĞLAR and GEREÖFFy noted "it is the controversies in Hungarian diaspora politics which impeded the development and the implementation of a comprehensive migration policy in Hungary" (ÇAĞLAR, A. and GereöFfY, A. 2008, 333). Contemporary kin-state politics are not without such controversies although they clearly communicate welfare in the homeland as a final goal together with collective rights and autonomy, which reflects that nowadays the balance between migratory and diaspora (ethnic) politics shifted towards the first one, primarily as a consequence of the extension of the Hungarian citizenship.

\section{Migration from Ukraine to Hungary: driving forces permeated by kin-state politics}

After some years of slightly declining number of migrants during the time of global economic crisis, the migration from Ukraine to Hungary has risen again since 2011. As 70 per cent of the migrants are ethnic Hungarians and 97 per cent are able to speak Hungarian (Kincses, Á. 2015), human mobility between Ukraine and Hungary can be considered as ethnic migration (see FeIschmidt, M. and ZaKariás, I. 2010). The migratory process is concentrated in geographical terms: 90 per cent of the migrants originate from Transcarpathia (KARÁCSONYI, D. and KincSEs, Á. 2010). Based on the statistics on birthplace, one can see a boost in the number of people born in Ukraine in the last five years, from around 20,000 in 2011 to 48,000 in 2015 (Figure 1). This increase can be explained only by the migration of Hungarian citizens from Ukraine triggered by the possibility to apply for non-resident Hungarian citizenship, as the number of Ukrainian citizens in Hungary did not reach this rate before 2011.

As a result, approximately 70,000 new citizenships were granted to Ukrainian citi- 


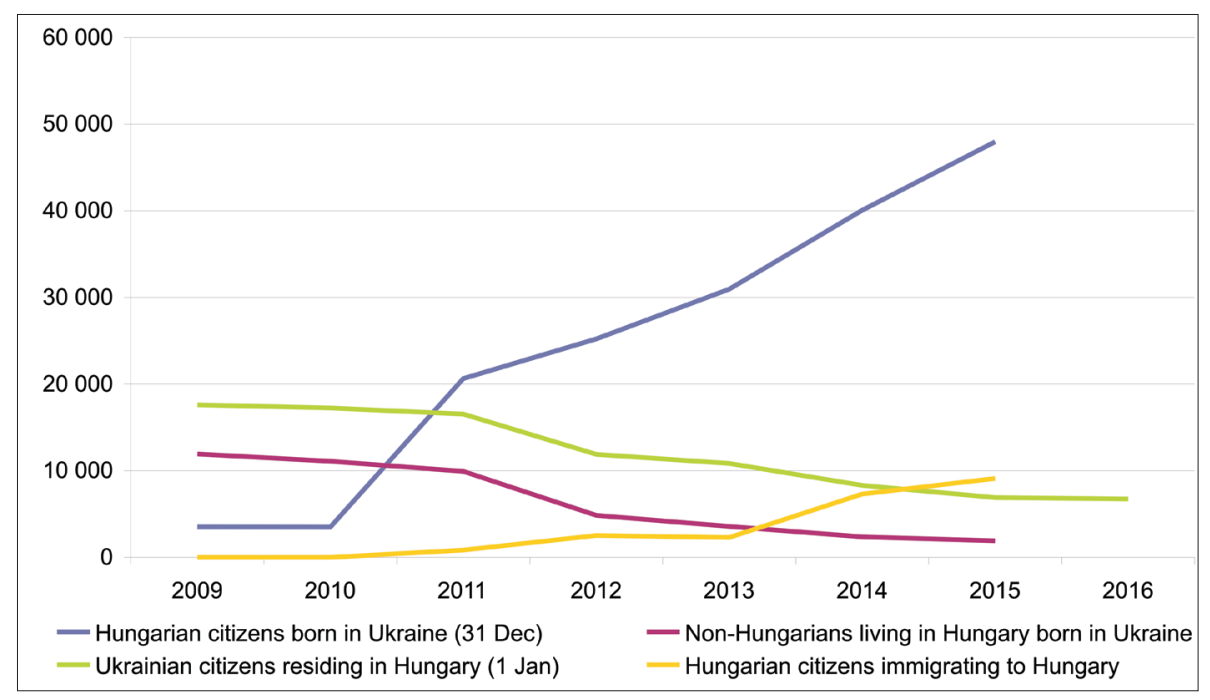

Fig. 1. Migration from Ukraine to Hungary by birthplace and citizenship. Source: Hungarian Central Statistical Office

zens between January 2011 and April 2014 (Soltész, B. and Zimmerer, G. 2014, 125); moreover, another 79,000 applications were submitted by June 2016. This means that application for Hungarian citizenship from Ukraine reached 149,000 (KáNTOR, Z. 2016), approximately the same number as that of ethnic Hungarians in Ukraine according to the 2001 census. This implies two conclusions: (1) as the number of ethnic Hungarians in Ukraine is estimated to have fallen to cca. 140,000 by 2010 due to the high rate of emigration (Molnár, J. and Molnár, D.I. 2005; KarÁcsonyi, D. and Kincses, Á. 2010), Hungarian citizenship must have been applied for by several non-Hungarians, ${ }^{4}$ and (2) more applications were submitted in the two years between April 2014 and June 2016 than in the previous three years. This shows that the Donbas conflict has triggered new wave of interest towards the simplified naturalisa-

\footnotetext{
${ }^{4}$ In line with these figures, news estimate the number of Ukrainian and Russian citizens who paid for fake language proficiency and fake Hungarian ancestors to gain Hungarian citizenship to tens of thousands. http://index.hu/gazdasag/2016/09/22/kettos_ allampolgarsag-biznisz_200_vadlott_kisvardan/
}

tion process (mostly in Transcarpathia). Even though Ukraine does not recognize dual citizenship, and those who acquire Hungarian citizenship risk to lose Ukrainian one, no sanctions have been applied against it in general (unlike in Slovakia) (Shevel, O. 2010).

Naturally, gaining citizenship is only the tool that facilitates migration, but the reasons for emerging wave of emigration from Ukraine should be traced back to several push and pull factors. The most important push factors are economic and security reasons. Main goals of Euromaidan, namely cleaning up corruption and putting the country's economy back on a fast track, seem to fall behind, ${ }^{5}$ while the devaluation of hryvna, the unleashed inflation, or the seven-fold increase of gas price laid extreme burden on population. ${ }^{6}$ Due to

\footnotetext{
${ }^{5}$ Ukraine's GDP fell by 7 per cent in 2014 and more than 10 per cent in 2015. This could not be counterbalanced by the slight increase $(2 \%)$ in the GDP in 2016.

${ }^{6}$ Meanwhile, food prices have multiplied, and the increase in wages and pensions (by $8 \%$ to $10 \%$ on average) have not followed the unleashing inflation. Inflation rate was 25 per cent in 2014, 43 per cent in 2015 and 12 per cent in 2016.
} 
the devaluation of the hryvnia, the value of the anyway low wages further decreased. In addition, war tax was levied and the wages of the public employee was frozen.

Even though Transcarpathia lies more than $1,000 \mathrm{~km}$ far from Donbas, the war has a heavy effect on the region as well. In Transcarpathia the wages are even 20 per cent lower than the Ukrainian average, ${ }^{7}$ while living costs are constantly increasing. Due to the devastating economic breakdown and the ongoing war in Donbas, the everyday living circumstances deteriorated rapidly in Transcarpathia. Thousands of men, especially Transcarpathian Hungarians, escaped to Hungary and later on to other EU countries to avoid the conscription and/or to seek job opportunities.

Since the central government in Kyiv is preoccupied with the ongoing hybrid war and its domestic consequences, Transcarpathia, as periphery both in geographical and political sense (Jordan, P. and Klemenčić, N. 2003), receives limited attention from the centre. While, on the one hand, it imposes heavy burden on the regional administration, on the other hand the limited attention of Kyiv and the proximity of border has its advantages as well: since the control of central power over Transcarpathia has been diminished and the Ukrainian state is not providing or not able to provide basic public duties (e.g. in the fields of education and health care) that increased the scope of action of the region's authorities to attract and accept external sources (i.e. funds by the Visegrad Countries, primarily Hungary, Czechia and Poland) to maintain the basic public services or launch development programmes.

All in all, the above factors like unemployment, economic downturn, falling living standards, feeling of insecurity and hopelessness contributed to the intensification of - already high - emigration of Transcarpathians.

\footnotetext{
${ }^{7}$ According to the State Statistics Service of Ukraine, per month average salary in Transcarpathia as of January 1, 2016 reached only 3,419 UAH (129 EUR) lagging behind Ukraine's average (4,362 UAH = 165 EUR).
}

We argue that the migration has become the new normal. This phenomenon threatens the existence and future of the Transcarpathia Hungarians:

„Lot of people left. For us to sustain the Hungarian community in Transcarpathia would have been essential. But the dual citizenship simplified their emigration. Not only to Hungary, but they simply left to England, Germany, Czechia. Wherever." (University lecturer, Uzhhorod)

At the same time, Hungary, similarly to other V4 countries, has been also facing serious and long-term demographic loss, which is exacerbated by heavy emigration to Western Europe in the past years resulting in a shortage in the skilled labour force in some sectors (Blaskó, Z. and FazeKas, K. 2016). This threatens the economic growth. The fastest way for the resupply of the missing labour force could be immigration (EMN 2015): for instance, according to the Confederation of Hungarian Employers and Industrialists Hungary should attract hundreds of thousands of skilled labour force from abroad. ${ }^{8}$ But hundreds of thousands of immigrant ethnic kin would threaten the future of transborder Hungarian communities and the main goals of Hungary's kin-state politics, thus only non-Hungarians would meet the criteria. The missing labour force could be substituted with migrants and refugees, who have been arriving in the EU in the last couple of years, but the Hungarian government follows a radical anti-immigration campaign and consistently refuses to accept non-European migrants or refugees (see Melegh, A. 2016).

Under such circumstances Ukrainians, physically and culturally closer to Hungarians, have become valuable assets; in addition, due to the crisis in East Ukraine thousands of underpaid, skilled workers became internally displaced to whom working in Hungary might represent a reasonable choice (e.g. due to the geographic vicinity in comparison to Czechia, for instance:

\footnotetext{
${ }^{8}$ http://index.hu/gazdasag/2016/07/05/magyar_ gyarosok_varganak_250_ezer_vendegmunkas_kell_ ide_azonnal/ (2016-08-15)
} 


\begin{abstract}
"It is a fact that lack of skilled workers in Hungary has reached an alarming level. And Hungary would not wish to rely on the recent middle-eastern migration wave when looking for replacement (...), thus, looking around in the region, and learning from the examples of other Visegrad Countries, we find the Christian Ukraine, with an enormous size of skilled labour force." (Representative of Hungarian kin-state politics regarding Transcarpathia, Budapest)
\end{abstract}

Summarizing the migratory processes from Ukraine to Hungary, we conclude that the amendment of the Hungarian Citizenship Law eased and speeded up emigration of Transcarpathia Hungarians to Hungary immediately after it came into force. Although this consequence of the law did not coincide with official principles of Hungary's diaspora (ethnic) politics, we argue that it was not unexpected for the legislator in 2010 as policy documents (indirectly) refers to it: Hungary and the whole region "cannot and does not intend to resist international trends of increasing mobility" (MPAJ 2011, 13). Nevertheless, this slight change favouring Hungary's migratory policies was only acceptable for decision-makers until the persistency of the Hungarian community in Transcarpathia was not threatened by serious emigration flow of ethnic Hungarians.

\section{Hungarian policy measures and emerging competition for human resources in Transcarpathia after the Euromaidan}

\section{Policies for sustaining Hungarian community in Transcarpathia ("staying in homeland")}

Transcarpathia did not receive special attention in the frame of the Hungarian kinstate politics in the first years after 2010. But the concatenation of events unfolded in Ukraine since the end of 2013, mainly the armed conflict in East Ukraine, dramatically changed the region's geopolitics and the migratory processes, which challenged Hungary's envisioned politics and enforced instant actions. Thus in the past years, the support for Transcarpathia by the Hungarian government was overrepresented compared to other neighbouring regions inhabited by Hungarians.

One of the main goals of the programmes implemented by the Hungarian government aimed at fostering prosperity of minority Hungarians in their homelands. However, in the background of these projects one can find other motivations than to help sustaining of ethnic Hungarians in regions they were born to namely to create clientelistic and patronage relationships extend across the border (Waterbury, M. 2010; Nagy, B. 2014; Pogonyi, S. 2017). Nevertheless, due to the limited available resources this goal can only be achieved in less developed, non-EU regions such as Vojvodina (Serbia) and Transcarpathia (KIss, T. 2015; BÁRDI, N. 2016). In addition, beyond supporting ethnic kin, the Hungarian government recently seems to buy influence in the whole region. The main purpose of this expansion is to actively engage in the quest for the most important resource of the weakened Ukraine, the labour force. In the followings, these two, simultaneously existing, sometimes closely intertwined strategies are divided into projects for "staying in homeland" and projects for "channelling labour forces to Hungary", although the dividing line in between is sometimes quite blurred. ${ }^{9}$

Even though it is quite difficult to separate, we try to structure the so-called ,staying in homeland" policy measures according to their proposed target groups. Some measures are beneficial for the wider community (including subsidies for institutions), while others target individuals. For instance, taking over some of the Ukrainian state functions in the fields of education, economic development and health care is considered to be valuable for the whole community. At the same time, it also means an opportunity for Hungary to strengthen its power position in Transcarpathia. With funding such tasks instead of the Ukrainian state, Hungary (like Czechia and Poland) - driven by their

\footnotetext{
${ }^{9}$ Only projects and policies started in the last five years are highlighted in this section.
} 
own urgent need of labour force replacement - were ready to jump into the slight power vacuum and have intensified and diversified their presence in Western Ukraine.

Among community support by Hungary the "Egán Ede program" should be highlighted, which provides 12 and 20 billion HUF (39 and 65 million EUR) non-refundable subsidy and preferential loan for enterprises in Transcarpathia in the fields of agriculture, tourism and manufacturing industry between 2016 and 2018. ${ }^{10}$

There are also numerous renovation projects since 2014, but especially from 2015, that were exclusively financed by the Hungarian state. To offer one example: in 2015 the dormitory in Uzhhorod University was thoroughly renovated (see more details in ERôss, Á. et al. 2016). Beside the development of the Hungarian Department of Uzhhorod National University, the Transcarpathian Hungarian College in Berehove, numerous schools, kindergartens or small health care units got refurbished. Due to the fact that Ukraine's economy is in a critical condition and regional funds and other support are very limited, such developments are appreciated by the local inhabitants, regardless of ethnicity.

Considering the second big group of supports, several applications are available for individuals. This includes for example the various educational scholarships which have been long time present in Hungarian kin-state politics or the novel form of financial subsidy - salary supplements. Latter was introduced in 2015/2016 school year and at first it was granted to those teachers and other administrative staff that work with Hungarian classes in Transcarpathia. Individual applications for this grant are collected in dedicated offices of the foundation of KMKSZ, one of the two

\footnotetext{
${ }^{10}$ Albeit non-Hungarians are also eligible for application, applications should be submitted in Hungarian, furthermore applicants or the representative of enterprise have to prove his/ her knowledge of the Hungarian language with Hungarian Certificate or documents proving Hungarian educational attainment or language certificate. http://www.eganede.com/
}

Hungarian ethnic parties in Ukraine. ${ }^{11}$ The aim of the salary supplement is to offer better living circumstances for those who work in Hungarian schools and it wished to reduce the emigration of teachers, which is by now a common problem in Transcarpathian schools (Kovály, K. et al. 2017).

Later on series of government declarations were accepted to offer similar individual financial aid for doctors, nurses, art teachers, journalists and clergymen who visibly indicate to offer patient care, courses, and any other services in Hungarian. Given the fact that neither Hungarian citizenship nor any statement of belonging to Hungarian community is a precondition, the subsidy cannot be considered as ethnically exclusionary. Rather it mirrors the double endeavour to look after the co-ethnic community in need, while at the same time, next to the quite easily accessible Hungarian citizenship, offers a tempting additional reason for non-Hungarians to set up links with local Hungarian community.

Policies for attracting Ukrainian workers to Hungary (" channelling human resources to Hungary")

Policy measures aiming to attract Ukrainian labour force to Hungary can be divided into two main categories: pragmatic and symbolic ones. The most important pragmatic measures were introduced in Hungary in 2015 and 2016: Hungarian Government implemented the necessary law amendments to be prepared to the reception of tens of thousands of non-EU-member (preferentially Ukrainian) guest workers (ÉLó, A. 2016). Besides, another brand new phenomenon is the education of Hungarian language for Ukrainians. While in case of ethnic Hungarians to acquire Hungarian citizenship has become pure formality, for non-Hungarian speaker Transcarpathians proving the mini-

\footnotetext{
${ }^{11}$ KMKSZ (Kárpátaljai Magyar Kulturális Szövetség - Ukrainian Hungarian Cultural Federation in Transcarpathia) has been strongly patronized by Fidesz in the last years.
} 
mal necessary language proficiency entails the only impediment. In recognition of this, in the 2015/2016 school year free-of-charge language courses were organised by Hungary. Thousand pupils study Hungarian as foreign language, 500 as extra-curricular activity while courses run on 105 sites throughout the region. The increasing interest towards Hungarian language has aroused business interest as well: Hungarian language courses are mushrooming in private language schools all around Transcarpathia (see Photo 1).

We argue that the motivation of Hungary in organizing free-of-charge language courses is quite clear: to attract desperately needed labour force. At the same time, the motivation of ethnic Ukrainians when learning Hungarian is to gain Hungarian citizenship which serve as a golden ticket to enter the EU job market:

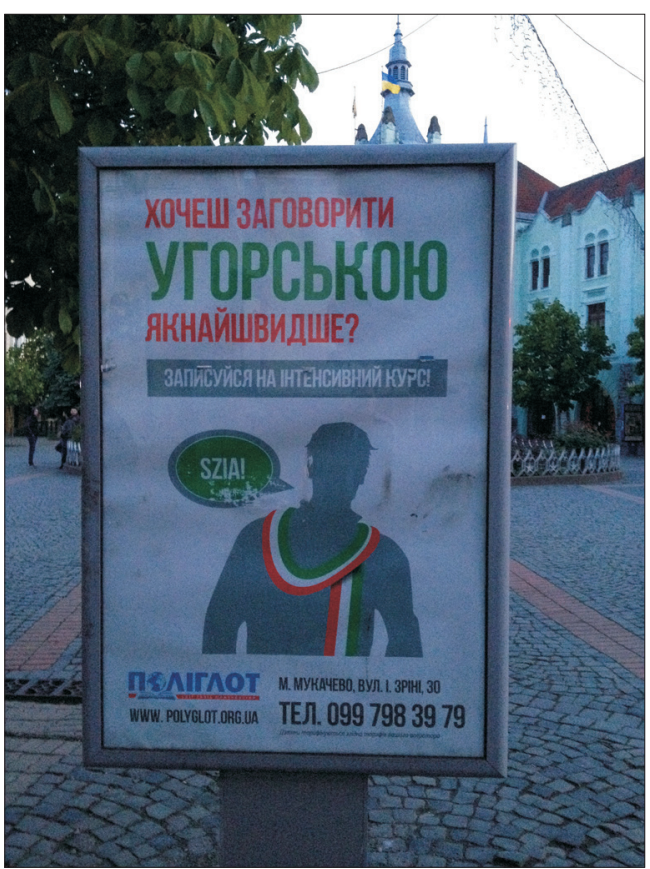

Photo 1. Poster advertising Hungarian language course in Mukacheve (May 2016). (Photo by Popovics, P.)
„Who is enrolled in a Hungarian class has a different motivation. Those who choose to learn English, German, or even Polish need the language either for business reasons or because they intend to find job in Poland. Those who visits Hungarian classes only wish to take the auth to the citizenship. Their only ambition with the classes is to learn enough to be able engage in a small talk while submitting the paperwork." (Language teacher, Uzhhorod)

The second group of actions belongs to the symbolic politics (or gesture politics), which aims at winning the sympathy of the Ukrainian population towards Hungary and Hungarians, thus increasing their interest in job opportunities in the western neighbour, non-Slavic country. As part of gesture politics Hungary financially covers such tasks and projects which would generally be the responsibility of the Ukrainian central or regional government/administration (for example, infrastructure development of various Ukrainian schools and establishment). To offer an examples, a statue of Taras Shevchenko, the Ukrainian national poet, was installed in Berehove, the cultural centre of Transcarpathian Hungarians with a 50-50 per cent Hungarian-Ukrainian ethnic ratio, financed by the Hungarian state.

The examples of the numerous projects listed above might illustrate that via diversified kin-state activism, Hungary is not merely nurturing good neighbourly and interethnic relations but taking actions in order to recruit a fresh active labour force among Transcarpathian Hungarians and Ukrainians, to buy influence and setting up a clientele:

„Essentially, the Hungarian presence substituting or replacing the Ukraine state in Transcarpathia has an ever growing influence." (Representative of Hungarian kin-state politics regarding Transcarpathia, Budapest)

This policy resonates to the features of trans-sovereign nationalism described by Csergô, Z. and Goldgeier, J. (2004). According to their description, kin-states apply tools and rhetoric of trans-sovereign nationalism to project a certain identity and political influence externally into neighbour- 
ing states. It does not merely target co-ethnic minority groups offering them the feeling of being incorporated to the nation, but at the same time it can be seen as a way to "settle score" with neighbours, shed light on the uneven power position between the states (Waterbury, M. 2014). Such a "petit imperialism" has been present in CEE states' politics. As Melegh, A. $(2002,129)$ described when analysing the discursive framework of Hungarian Status Law "frustrated political communities classed as inferior find their own Easterners to exclude, to control and to civilize" thus inviting post-colonial critique to the explanation of kin-state politics.

\section{Competing kin-state politics: quest for the labour force}

The geopolitical shift and the relative power vacuum created by the diminished power of the Ukrainian state induced activity of Poland and Czechia as well. These activities mostly aimed at attracting human resources from Ukraine, as from agriculture to IT or tourism, both Czechia and Poland are in demand of labour force (Leontiyeva, Y. 2014; Józwiak, I. and Piechowska, M. 2016). ${ }^{12}$ In addition, the Visegrad Countries "openly state that they prefer migrants from Ukraine due to their cultural affinity" (JARoszewicz, M. $2015,5)$. Before the introduction of simplified naturalization, Hungary was more of a blind spot on the map of Ukrainians seeking a job abroad due to the serious linguistic barrier (Hungarian, unlike Polish and Czech, is not a Slavic language) and offering lower wages than Poland or especially Czechia. In the quest for a Ukrainian labour force by the Visegrad countries, Hungary, thus, has been in a handicapped position. Furthermore, both Poland and the Czech Republic have been traditional destination countries for Ukrainian migrants looking for short or

\footnotetext{
${ }^{12}$ As Uherek phrased Czechia (at least until the period of 2008 economic crisis) "treated Ukraine as a reservoir of inexpensive flexible labour force" (UHEREK, Z. 2016, 5).
}

long term occupation (LeNDEL, M. 2015). Due to cultural, geographical and linguistic vicinity, the attraction of Ukrainian workers seems obvious choice, thus both countries elaborated complex procedures to enhance migration from Ukraine.

In Poland Ukrainians compose the biggest immigrant community. The recent crisis in Ukraine triggered new wave of migration which is clearly reflected in Polish statistics (Józwiak, I. and Piechowska, M. 2016). Poland has accepted series of administrative measure to facilitate migration. Polish Charter (Karta Polaka) came into effect in 2008 offers unrestricted stay and access to the Polish labour market, education and social services targets only foreigners of Polish origin; and it should be evaluated as quasi-citizenship (Waterbury, M. 2009; KarolewsKi, I.P. 2015). But since the most of the immigrants to Poland is ethnic Ukrainians (Jóźwiak, I. and Lugosi, N. 2016) who cannot apply for Polish Charter, Poland introduced the simplified procedures of gaining short or long term work permits opened for Ukrainians as well (JARoszewicz, M. 2015). That procedure makes the relatively cheap workforce available for Polish business sector while - since the Polish state does not carry the costs of integration programmes or migrant's social accommodation - it is also a cost effective solution to tackle the labour shortage in certain segments of Polish economy (Józwiak, I. and Piechowska, M. 2016). Furthermore, Polish universities offer tuition free education and scholarships for Ukrainian citizens. As a result, in 2015, 20,000 Ukrainian students have pursued studies in Polish universities. Even though Poland is more active in Western Ukrainian territories once belonged to Poland, in the last couple of years Polish educational institutions so as companies intensified their presence in Transcarpathia as well (Photo 2).

Despite major immigrant or refugee influx is not reported in Czech statistics from postconflict Ukraine (UHEREK, Z. 2016), the earlier existing migration trends and numbers seem to stabilize. Nevertheless, certain new fea- 


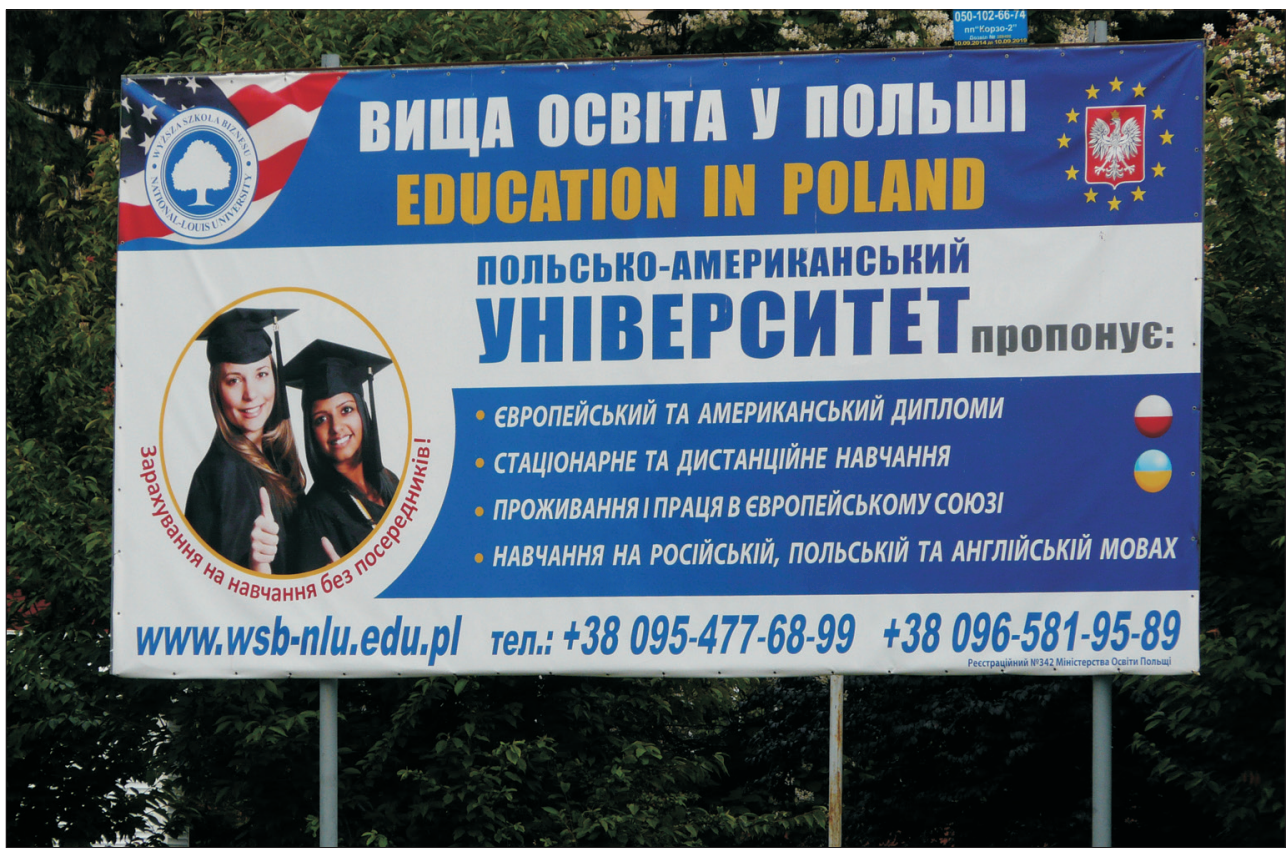

Photo 2. Advertisement of a Polish university in Uzhhorod, the seat of Transcarpathia. (Photo by Erőss, Á.)

tures have evolved, for instance the increase of permanent residence permit holders in Czechia might suggest the growing intention among Ukrainian migrants to settle for a longer period in the country (Drbohlav, D. and SEIDlová, M. 2016). Relevant to present article is the appearance of the so called "Polish route": it refers to a recently reported phenomenon when Ukrainian citizens - to avoid the expensive and far more difficult Czech visa procedure - apply for Polish visa to enter Czechia, their original destination (Drbohlav, D. and Seidlová, M. 2016, 122).

Although the Czech Republic did not introduce any measure like Polish Charter, but it also intensified its presence in Ukraine: in 2014 five new visa issue offices were opened in the country, out of which one is in Uzhhorod, Transcarpathia. At the same year, after Kyiv and Lviv, the third Czech consulate was opened in Uzhhorod. Furthermore, there is an on-going negotiation about a centre that would assist Ukrainian citizen to access the Czech labour market. ${ }^{13}$ Czechia financially supports the teaching of Czech language in several schools in Transcarpathia.

Recently, the plan of opening a Czech Cultural Centre in Uzhhorod also appeared in press. ${ }^{14}$ The Centre would offer Czech language courses and the language exam issued by the Centre would exempt students taking another language exam when applying for Czech universities. Similarly to Poland, Czechia also offers a variety of scholarships for Ukrainian youth. Next to the close linguistic ties, historical contacts from Czechoslovak times between 1919 and 1939, and the already functioning migration networks the above policies also contribute to that among Transcarpathians Czechia is the most popular migration destination (see Č́ERMÁKOVÁ, D. 2014; Drbohlav, D. and Valenta, O. 2014;

\footnotetext{
${ }^{13}$ http://zak.depo.ua/ukr/zak/v-uzhgorodi-vidkriyuttsentr-dlya-poshuku-roboti-v-chehiyi-08092015131700 (2016-10-10)

${ }^{14}$ http://uzhgorod.net.ua/news/79760 (2016-10-15)
} 
KovÁLy, K. and ČERMÁKovÁ, D. 2016) offering various job opportunities (Photo 3).

Other countries neighbouring Transcarpathia (Slovakia, Romania) does not attract significant number of guest workers from Ukraine. Romania offer non-resident citizenship on request for ethnic kin (primarily in Moldova and Ukraine) since 1991, expanded to third-generation descendants of former Romanian citizens in 2009 (Iordachi, C. 2013; WATERbURy, M. 2014), but in Transcarpathia, gaining Romanian (as EU) citizenship encourage for working in western countries, chiefly in Czechia, rather than in Romania (JóźwIAK, I. 2014).

\section{Conclusion}

The Ukraine crisis and its consequences, the overall geopolitical shift in regional power relations generated novel threats and opportunities for the Hungarian kin-state politics in which its flagship project, the preferential (re)naturalization, plays a crucial role.
When in 2010 the Hungarian parliament accepted the amendment of Hungarian Citizenship Law, enabling former citizens of the Hungarian Kingdom to acquire Hungarian citizenship without residing in Hungary, it was communicated by the government as a gesture, the symbolic reunification of the nation, rather than a policy with practical and direct effect. We argue that following the outbreak of the Ukraine crisis this has changed in regards of Ukraine due to the boosting out-migration of ethnic Hungarians and emerging slight power vacuum in the western peripheries of Ukraine. Moreover, severe demographic and labour shortage in Hungary also contributed in re-evaluating aims and tools of Hungary's kin-state politics in Ukraine. The new circumstances simultaneously provided opportunities and posed a threat to the well-built system of Hungarian kin-state politics that was necessary to tackle, thus it resulted in major modification of policies targeting Transcarpathia.

Following 2014, the Hungarian government has elaborated several economic

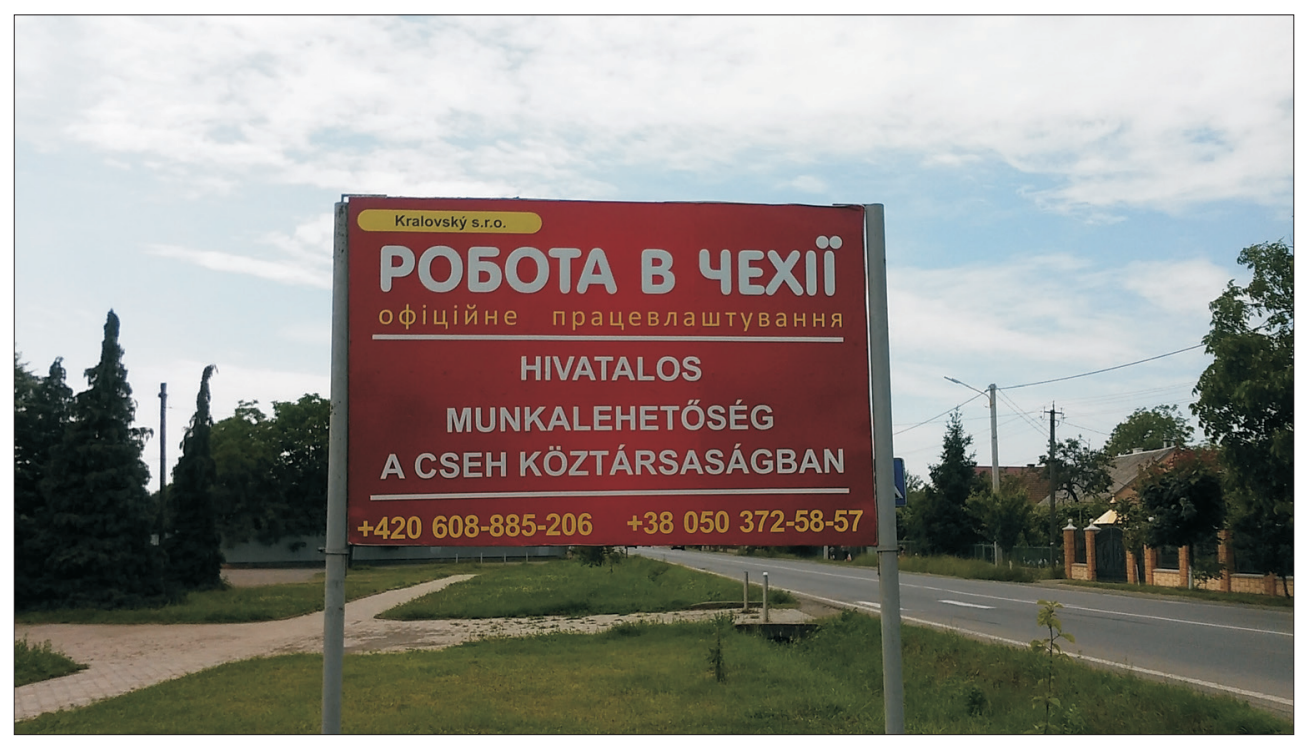

Photo 3. Bilingual (Ukrainian and Hungarian) billboard in the outskirts of Uzhhorod offering legal job opportunities in Czechia. (Photo by Tátrai, P.) 
and cultural programmes and projects in Transcarpathia targeting Hungarian and non-Hungarian communities as well. These projects, measures, and occasionally the takeover of some of the Ukrainian state functions - favouring not only the ethnic Hungarians but the whole population of Transcarpathia - simultaneously serve Hungary's ethnopolitical goals (i.e. maintaining the Hungarian community in Transcarpathia), the expansion of Hungary's positions in Ukraine and the enticement of the Ukrainian workforce to Hungary. The policies of "staying in homeland" and "channelling human resources" have reproduced the traditional conflict of interest in Hungary's kin-state activism sometimes neutralizing each other.

Beside Hungary, Poland and the Czechia has also been interested in expanding their influence in Ukraine to attract human resources. As a consequence, competing kin-state politics emerged among V4 countries. In this race, in which previously Hungary occupied a disadvantageous position, the easily accessible Hungarian citizenship might be suitable tool to reposition Hungary among V4 countries in the emerging quest for the Ukrainian labour force. Thus we argue it is not by chance that Hungarian authorities turn a blind eye to the tens of thousands of individuals with nonHungarian background who applied for (and gained) Hungarian citizenship.

All in all, the status of Hungarian citizenship as an element of kin-state politics targeting transborder Hungarian communities has been enriched in Transcarpathia where - especially following 2014 - it rather represents a pragmatic tool embodying practical opportunities, even material benefits tempting for non-Hungarians as well. Nowadays in Transcarpathia Hungarian citizenship helps to escape conscription and serves as a golden ticket to enter not only the Hungarian, but more the European Union's job market or education system.

However, up until nowadays these policy measures by Hungary stimulated almost exclusively the emigration of Transcarpathian Hungarians, rather than attracting ethnic
Ukrainian workforce, opening a new mobility channel that leads directly to Western Europe. Consequently, Hungary's kin-state politics not only contribute to the decrease of the number of Transcarpathian Hungarians, but there is a high risk that - with their Hungarian citizenship - they will resettle in Western Europe, not in Hungary.

Acknowledgement: The research was carried out with the financial support of the International Visegrad Fund's Standard Grant project ('Cross-border cooperation at the time of crisis on neighbour's soil', Nr: 21510578) and the project titled 'Regional processes and global challenges following 2008 crisis in Ukraine and Hungary' (Nr. NKM-90/2017) carried out in the framework of Hungarian-Ukrainian bilateral academic exchange programme.

\section{REFERENCES}

Agarin, T. and Karolewski, I.P. 2015. Extraterritorial Citizenship in Postcommunist Europe. London, Rowman \& Littlefield.

BÁRDI, N. 2011. The Policy of Budapest Governments towards Hungarian Communities Abroad. In Minority Hungarian Communities in the Twentieth Century. Eds.: BÁrdi, N., Fedinec, Cs. and Szarka, L., New York, Columbia University Press, 456-467.

BÁRdi, N. 2016. A budapesti kormányzatok magyarságpolitikája (Kin-state politics of Hungarian governments). Paper presented at the conference "A megmaradás útjai - helyzetkép a külhoni magyarságról" in Budapest, 30 May 2016.

BAuвöck, R. 2007. The trade-off between transnational citizenship and political autonomy. In Dual citizenship in Global Perspective. Eds.: FAIst, T. and KIvisto, P., New York, Palgrave -MacMillan, 69-91.

Bauböck, R., Ersbøll, E., Groenendijk, K. and Waldrauch, H. 2009. Citizenship Policies in the New Europe. IMISCOE Research. Amsterdam, Amsterdam University Press.

Blaskó, Z. and Fazekas, K. eds. 2016. Munkaeröpiaci tükör (Report on labour market). Budapest, MTA KRTK.

Brubaker, R. 1996. Nationalism Reframed: Nationhood and the National Question in the New Europe. Cambridge, Cambridge University Press.

ÇAĞlar, A. and GereöfFY, A. 2008. Ukrainian Migration to Hungary: A Fine Balance between Migration Policies and Diaspora Politics. Journal of Immigrant \& Refugee Studies 6. (3): 326-343.

Castles, S. and Davidson, A. 2000. Citizenship and Migration. Globalization and the Politics of Belonging. London, Palgrave-MacMillan. 
Čermáková, D. 2014. Migration between the EU, V4 and Eastern Europe: the present situation and the possible future. The perspective of Czechia. In Forecasting Migration Between the EU, V4 and Eastern Europe. Impact of Visa abolition. Eds.: Jaroszewicz, M. and LesińsKA, M., Warsaw, Centre for Eastern Studies, 109-121.

Csergó, Z. and Goldgeier, J. 2004. Virtual Nationalism in Comparative Context: How Unique Is the Hungarian Approach? Central European Political Science Review 16. 40-56.

Drbohlav, D. and Seidlová, M. 2016. Current Ukrainian migration to Czechia: Refuge for economic migrants rather than for refugees. In Ukrainian migration in times of crisis: Forced and labour mobility. Eds.: Drbohlav, D. and Jaroszewicz, M., Prague, Charles University, Faculty of Science, Department of Social Geography and Regional Development, 95-127.

Drbohlav, D. and Valenta, O. 2014. Czechia: the main immigration country in the V4. In: Discovering migration between Visegrad countries and Eastern Partners. Eds.: Erőss, Á. and KarÁcsonYI, D., Budapest, MTA RCAES Geographical Institute, 41-71.

ÉLő, A. 2016. Ukránok a spájzban (Ukrainians at the gate). Heti válasz, 22 Sept. 2016. 20-22.

EMN 2015. Determining labour shortages and the need for labour migration from third countries in the EU. Hungary. EMN Focussed Study. http://ec.europa. eu/home-affairs/sites/homeaffairs/files/whatwe-do/networks/european_migration_network/ reports/ docs/emn-studies/13a_hungary_labour_ shortages_study_en_may_2015.pdf

Erôss, Á., Kovály, K. and TÁtrai, P. 2016. Effects of the Ukrainian crisis in Transcarpathia: the Hungarian perspective. Warsaw, Centre of Migration Research, (CMR Working Papers 92). Available at: http://www.migracje.uw.edu.pl/publikacje/effects-of-the-ukrainiancrisis-in-transcarpathia-the-hungarian-perspective-2/

Faist, T. and Kivisto, P. 2007. Dual citizenship in Global Perspective. New York, Palgrave-MacMillan.

Feischmidt, M. and Zakariás, I. 2010. Migráció és etnicitás. A mobilitás formái és politikái nemzeti és transznacionális térben (Migration and ethnicity. Forms and politics of migration in national and transnational space). In Etnicitás. Különbségteremtó társadalom. Ed.: Feischmidt, M., Budapest, Gondolat Kiadó-MTA Kisebbségkutató Intézet, 152-169.

Fowler, B. 2002. Fuzzing Citizenship, Nationalising Political Space: A Framework for Interpreting the Hungarian 'Status Law' as a New Form of Kin-state Policy in Central and Eastern Europe. Economic and Social Research Council Working Paper 40. (2): 177-238.

Hatvany, C. 2006. Legitimacy of Kin-State Politics: A Theoretical Approach. Regio: Minorities, Politics, Society 6. (1): 47-64.

HowARD, M.J. 2009. The politics of citizenship in Europe. New York, Cambridge University Press.

IordaCHI, C. 2013. EUDO Citizenship Observatory. Country Report: Romania. San Domenico di
Fiesole: European University Institute. http:// eudo-citizenship.eu/admin/? p=file\&appl $=$ countryProfiles $\& \mathrm{f}=2013-19-$ Romania.pdf

Jaroszewicz, M. 2015. The migration of Ukrainians in times of crisis. Warsaw, Centre for Eastern Studies, http://www.osw.waw.pl/en/publikacje/osw-commentary/2015-10-19/ migration-ukrainians-timescrisis (2016-10-10)

JoRdan, P. and KLEMENčić, M. 2003. Transcarpathia - Bridgehead or Periphery? Eurasian Geography and Economics 46. (7): 497-513.

JóźWIAK, I. 2014. Ethnicity, Labour and Mobility in the Contemporary Borderland. A Case Study of a Transcarpathian Township. Central and Eastern European Migration Review 3. (1): 27-39.

JóźWIAK, I. and Lugosi, N. 2016. The Role of Nationalist Narratives and Myths in the Changing Dynamics of Mobility between Ukraine and its Western Neighbours. In Social Geographical Challenges and Search for Adequate Answers in East-Central Europe of the $21^{\text {st }}$ Century. Ed.: Berghauer, S., Berehove, 123-133.

Józwiak, I. and Piechowska, M. 2016. Crisis-driven Mobility between Ukraine and Poland. What Does the Available Data (Not) Tell Us. Warsaw, Centre of Migration Research, CMR Working Papers 99. Available: http://www.migracje.uw.edu.pl/publication_type/ publicat ions-cmr/

Kántor, Z. 2014. Hungary's Kin-State Politics, 2010-2014. Minority Studies 17. 23-32.

KÁntor, Z. 2016: Nemzet, autonómia, kettôs állampolgárság (Nation, autonomy, dual citizenship). Paper presented at the conference titled "A megmaradás útjai - helyzetkép a külhoni magyarságról" in Budapest, 30 May 2016.

Karácsonyi, D. and Kincses, Á. 2010. Az elvándorlás hatása a kárpátaljai magyarság helyzetére (The effect of immigration on the situation of Transcarpathian Hungarian population). Földrajzi Közlemények 134. (1): 31-44.

Karácsonyi, D., Kocsis, K., Kovály, K., Molnár, J. and Póti, L. 2014. East-West dichotomy and political conflict in Ukraine - Was Huntington right? Hungarian Geographical Bulletin 63. (2): 99-134.

Karolewski, I.P. 2015. The Polish Charter: Extraterritorial Semi-Citizenship and Soft Power. In Extraterritorial Citizenship in Postcommunist Europe. Eds.: Agarin, T. and Karolewski, I.P., London, Rowman \& Littlefield, 65-88.

Kincses, Á. 2015. International Migration Diversity in Hungary in the 2011 Population Census Data. Regional Statistics 5. (2): 108-124.

KIss, T. 2015. Marginalizáció, etnikai párhuzamosság és aszimmetrikus akkomodáció. Az erdélyi magyar közösséget érintő társadalmi és politikai folyamatok (Marginalization, ethnic parallelism, asymmetric accommodation. Social and political processes of Transylvania Hungarians). Magyar Kisebbség 20. (1-2): 30-64. 
KovÁcs, M. 2007. The politics of dual citizenship. Dual Citizenship in Global Perspective: from Unitary to Multiple Citizenship. In Dual Citizenship in Global Perspective. Eds.: Faist, T. and Kivisto, P., New York, Palgrave-MacMillan. 92-112.

KovÁly, K. and Čermáková, D. 2016. The role of social capital in economic life of the Ukrainian entrepreneurs in Czechia. AUC Geographica 51. (2): 135-144.

Kovály, K., Erôss, Á. and TÁtrai, P. 2017. „Hát megpróbálunk küzdeni": átalakuló boldogulási stratégiák Kárpátalján az Euromajdan után (,,So we try to strive": livelihood strategies in transition after the Euromaidan in Transcarpathia, Ukraine). Tér és Társadalom 31. (2): 3-22.

Kulu, H. 2000. Policy towards the Diaspora and Ethnic (Return) Migration: An Estonian case. GeoJournal 51. (3): 135-143.

Lendel, M. 2015. Migration to V4 countries: A Ukrainian Perspective. In Current Migration trends in V4 countries: Focus on migration from Ukraine. Ed.: Benč, V., Prešov, Research Centre of the Slovak Foreign Policy Association, 9-20.

Leontiyeva, Y. 2014. The Education-Employment Mismatch among Ukrainian Migrants in the Czech Republic. Central and Eastern European Migration Review 3. (1): 63-84.

Melegh, A. 2002. Globalization, nationalism and petit imperialism. Romanian Journal of Society and Politics 2. (1): 115-129.

Melegh, A. 2016. Unequal Exchanges and the Radicalization of Demographic Nationalism in Hungary. Transactions. East European Journal of Society and Politics 2. (4): 87-108.

Molnár, J. and Molnár, D.I. 2005. Kárpátalja népessége és magyarsága a népszámlálási és népmozgalmi adatok tükrében (Demographic process of ethnic Hungarians in Transcarpathia). Uzhhorod, Kárpátaljai Magyar Pedagógusszövetség.

MPAJ 2011. Policy for Hungarian Communities Abroad The Strategic Framework for Hungarian Communities Abroad. Budapest, Ministry of Public Administration and Justice (MPAJ), State Secretariat for Hungarian Communities Abroad. Available at: http:// nemzetiregiszter.hu.

NAGY, B. 2014. Az állampolgárság mint stigma: az állampolgárság hátrányai (Citizenship as stigma: the drawbacks of citizenship). Regio 22. (1): 36-73.

PAPP, Z.A. 2017. Trickster Logic in the Hungarian Citizenship Offer. Nationalism and Ethnic Politics 23. (1): 18-32.

Perchinig, B. and Bauböck, R. 2005. Preface. In Acquisition and Loss of Nationality. Policies and Trends in 15 European States. Volume 2: Country Analyses. IMISCOE Research. Eds.: Bauböck, R., Ersbøll, E., Groenendijk, K. and Waldrauch, H., Amsterdam, Amsterdam University Press, 11-17.

Pogonyi, S. 2011. Dual citizenship and sovereignty. Nationaliaties Papers 39. (5): 685-704.
Pogonyi, S. 2014. Four Patterns of Non-resident Voting Rights. Ethnopolitics 13. (2): 122-140.

Pogonyi, S. 2015. Transborder Kin-minority as Symbolic Resource in Hungary. Journal on Ethnopolitics and Minority Issues in Europe 14. (3): 73-98.

Pogonyi, S. 2017. Europanization of Kin-Citizenship and the Dynamics of Kin-Minority ClaimMaking: The Case of Hungary. In Problems of PostCommunism. Published online 07.06.2017. http:// dx.doi.org/10.1080/10758216.2017.1329630

Pogonyi, S., Kovács, M. and KörtvéLyesi, Z. 2010. “The Politics of External Kin-State Citizenship in Eastern Europe." EUDO Citizenship Observatory. San Domenico di Fiesole, European University Institute. Available at: http://eudo-citizenship.eu/docs/ECE comp report.pdf

Shevel, O. 2010. Country Report: Ukraine. EUDO Citizenship Observatory. San Domenico di Fiesole, European University Institute. http:// eudo-citizenship.eu/admin/?p=file\&appl =country Profiles\&f=Ukraine.pdf

Sievers, W. 2009. 'A call to kinship?' Citizenship and migration in the new Member States and the accession countries of the EU. In Citizenship Policies in the New Europe. IMISCOE Research. Eds.: BAuвÖск, R., Perchinig, B. and Wiebke, S., Amsterdam, Amsterdam University Press, 439-457.

Soltész, B. and Zimmerer, G. 2014. Migration between the EU, V4 and Eastern Europe: the present situation and possible future. The perspective of Hungary. In Forecasting Migration Between the EU, $V 4$ and Eastern Europe. Impact of Visa abolition. Eds.: Jaroszewicz, M. and Lesińska, M., Warsaw, Centre for Eastern Studies. 122-138.

То́тн, J. 2006. Kin Minority, Kin-state and Neighbourhood Policy in the Enlarged Europe. In Beyond Sovereignty: From Status Law to Transnational Citizenship? Eds.: IedA, O. et al. Sapporo, Slavic Research Centre, Hokkaido University, 73-88.

Uherek, Z. 2016. Migration from Ukraine to the Czech Republic with Respect to the War Conflict in Eastern Ukraine. Warsaw, Centre of Migration Research. CMR Working Papers 93. Available at: http://www. migracje.uw.edu.pl/publikacje/migration-fromukraine-to-the-czech-republic-with-respect-to-thewar-conflict-in-eastern-ukraine-2/

Waterbury, M.A. 2009. From Irredentism to Diaspora Politics: States and Transborder Ethnic Groups in Eastern Europe. Global Migration and Transnational Politics Working Paper 6. Available at: http://cgs. gmu.edu/publications/gmtpwp/gmtp_wp_6.pdf

Waterbury, M.A. 2010. Between State and Nation. Diaspora Politics and Kin-state Nationalism in Hungary. New York, Palgrave MacMillan.

Waterbury, M.A. 2014. Making Citizens Beyond the Borders. Non-resident Ethnic Citizenship in PostCommunist Europe. Problems of Post-Communism 61. (4): 36-49. 